\title{
Winter's Walk: All the Light I Hold in This Moment
}

\author{
Lynn Fels
}

\begin{abstract}
How do we enlarge the space of the possible to encourage our students to notice the educational, social, economic, communal, and political scripts that perform us? Academic performance imagines new ways of performing research. Conventional academic performances have been interrupted. Be aware. We can never take for granted the performance that is us. I want to be awakened to the gaps and absences in the performances that our students offer us, as we create space for them to perform in our classrooms, on school stages, in our hearts. How might performance become an action site of resistance, of resolution, of advocacy, of invitation, of renewal?

In the midst of winter, I found within me an invincible summer. (Albert Camus)

Last Thursday, I followed a forest trail in Pacific Spirit Park to my writing class that I am auditing this winter. Karen Meyer is teaching the course, one she created years ago. This trail is familiar and unfamiliar. In the 13 years since I last taught at the University of British Columbia, deciduous trees have edged closer along the path, edging out the light. The girths of the redwoods have widened. Time weighs on the arcing snow-covered branches overhead.
\end{abstract}

My boots sink into snow.

As I walk, I compose the commentary that you are now reading. I practice openings, sounding words raw into the cold air.

How might I speak to the role of performances in educational practices?

I want to share with you all those who have reimagined the performance of scholarship, research, and teaching in ways that resonate with me. I want to introduce you to those whose words, teachings, actions have touched me; those who gave me permission to be who I am, as a scholar, an educator, a writer.

I remember Carl Leggo reading from Growing up perpendicular on the side of the hill. His voice rides the bumps and flights of images as wildly as the boy sliding on his toboggan in his poem. I confess to Carl that I had made a mistake, I had registered into two 601 seminars. He tells me there are no mistakes.

I remember Patrick Verriour, my thesis supervisor, leading a drama class. He asks us to position ourselves in relationship to an empty chair to illustrate high or low status. Standing behind the chair, I imagine myself to be a guard, protecting the king. The student standing on guard next to me is contemplating treason.

I remember Karen Meyer, whose class I am now trudging towards, she a science educator, and I, newly arrived in my graduate program. We dream new possible ways of teaching science through drama. 
I remember our play, Light Sound Movin' Around: What are Monsters Made of? written by our students, which they performed for the elementary school children who walked up to the university in Jackson Pollack splashes of boots, raincoats, and umbrellas. The play features a six-foot tall pink bunny named Einstein who spouts scientific definitions of concepts he doesn't understand, and Wendy, a 10-year-old girl who puts into action the science of shadows to defeat the Monster. "I'm glad this play is about science," is overheard by one of our cast, words whispered by one young audience member to another.

And I remember the drama students in London, Ontario, with whom I worked to create a reader's theatre piece for the London International Children's Festival. Hundreds of children created masks of animals and birds, on picnic tables in the sunshine, and then slipped into the belly of the Story Dragon to perform, roaring and squawking the play into life.

Light fades, as afternoon falls into dusk. I check my watch and then lengthen my stride. I have forgotten the time required to walk the distance between home and the university. Shadows darken the path. I quicken my pace.

I want to rant and rage. The only light switch in my newly renovated classroom is outside the door. "Black out!" I shout, and students close their eyes. "Lights" I cry when the group is assembled and ready to begin their scene. Eyes open and close on my command. I am currently in negotiation for theatre lights. The black theatre curtains, dry cleaned and ready, will be hung back up on their hooks. All we need for theatre to exist, argues Peter Brook, is an empty space, someone to walk across, and someone to witness.

I am troubled. Arts programs, arts specialists, those of us who love the arts are an endangered species, disappearing as budgets tighten. Time and priorities shift. Does the burden fall upon artists and arts educators once again to prove the value of the arts?

I want to celebrate. I applaud educators and scholars who engage in arts-based research and its many forms and practices such as a/r/tography, poetic inquiry, performative inquiry, mixed visual arts media inquiry. Meghan Parker, an arts educator in a North Vancouver school, graduates with a nonfiction comic book thesis for her master's degree. Academic performance imagines new possible templates, new ways of performing research. Conventional academic performances have been temporarily (permanently?) interrupted. Be aware. Resistance to our free play in the academy lurks in the shadows. We can never take for granted the performance that is us. Stay tuned.

I want to be awakened to the gaps and absences in the performances that our students offer us, as we create space for them to perform in our classrooms, on school stages, in our hearts. How might performance become an action site of resistance, of resolution, of advocacy, of invitation, of renewal?

How do we enlarge the space of the possible to encourage our students to notice the educational, social, economic, communal, political scripts that perform us? And invite our students into performance so that we might hear their voices, their ideas, their passions, their concerns? Performance as creative action and offering invites us into shared vulnerability and creativity, as we enter into play to see what arrives. What is lost when we fail to invite our students into play? When we fail to play ourselves? 
How might we learn to recognize and disrupt the scripts that perform us?

Madeleine Grumet ${ }^{1}$ whispers, "Tread lightly, oh so lightly." And as the snow yields beneath my boots, I lighten my step.

Ghosts whisper in my ear as I lay down a path in walking. My grade one teacher, Mrs. Gorie, hands me the role of Miss-Polly-Put-the-Kettle-On for my first Christmas play. I fall in love with the boy playing the Mad Hatter, four grades ahead. In grade four, Mrs. Mayville announces that our play's leading actress, a girl in grade five, has the chicken pox. I am chosen and experience my first stage kiss. In grade seven, Miss Owen directs a 13-year-old Hamlet, awkwardly brandishing a cardboard sword, my braces glinting in the stage lights. So, not surprisingly, I fall in love with theatre, fail epically, and turn to education.

I learn to be a learner in the presence of children.

A child's tug on the sleeve. I am working with a grade two class to improvise the first scene of our play, Jack and Jill and the Beanstalk. Jill is Jack's sister. One of the grade two students balks. He doesn't want to be the cow.

"But you can be any kind of cow you want!" I assure him.

"Any type of cow?" I nod. He grins.

Light enters the dark corners of his resistance.

"I'll be a cow who plays hockey in the NHL. I'Il bring my hockey net, and helmet and goalie stick..."

A cow in the NHL?

How to respond to this child?

I hesitate.

To say no would reinforce that I as director, have full authority.

My script is what matters. There is no cow in the NHL.

To say yes welcomes a child's imagination, passion, curiosity into play. Children bring forth new possible worlds for us to embrace...or refuse.

The children eye me speculatively. Whose performance is being judged?

Brazilian educator, Paulo Freire encourages educators to recognize the expertise of lived experience. I look at the faces of my students, outside of school, they live their expertise.

Vancouver artist, Patty Fraser encourages community artists to listen to what is present in the room. I struggle to listen beyond my own doubts.

And philosopher, Hannah Arendt asks, Who are you?

Who will you choose to become in the presence of this child?

Tread gently.

Performance is not a tool, nor strategy, nor output, nor process, nor product. 
Not walls of cement, but...the melodies of your temperatures.

Think of performance as verb and noun, creative action and offering. We perform and are performed by the environments and contexts within which we dwell. The arts invite us to perform ourselves into presence through a communal journey of inquiry, curiosity, resistance, (com)promise, and creativity. Performance calls attention to what or who is absent in the scripts that perform our lives.

Performance simultaneously offers and expresses who we are, who we might become, what matters, how we wish to engage in the world. Our actions are shaped by and shape the forms within which we engage. Just as a waterfall is shaped by the fall of water on rocks, so, over time, water carves its presence in the rocks. Performance shakes us awake like tremors in the earth, interruptions unsettle, disrupt, alarm, awaken.

We perform our presence in the presence of others, and in so doing, invite new possible worlds into being. Performance is an offering. A gift.

Hannah Arendt asks of educators if they love children enough to invite them into the world's renewal. Performance matters. How we perform and are performed requires scrutiny, a practice of noticing. Do not, as Maxine Greene, echoing Thoreau of Walden Pond, warns educators, sleepwalk through your life.

Performance reveals who we are, the choices we make, the context that informs us. Performance witnesses our fragilities, our willingness to risk, our failure to engage, our gestures of invitation. Performance in educational practices invites students to be creators, dreamers, makers, revolutionists. Through performance, educators may offer students opportunities to bring their voice into the conversation in ways that will enlarge the space of the possible, to express what matters, to imagine what has not yet been imagined.

Listen. Performance embodies the heartbeat of our lives, our struggles, our joys, our being impossibly regrettably human. The ephemeral temporality of performance speaks to our human condition. Performance calls us to remember our responsibility for the nonhuman, for each other, for our environment. Performance has the potential to nurture and give voice to how we might perform as citizens in today's world, and how our children may create and perform tomorrow's future.

Here is an offering. A performance. Created in the midst of winter by four women in my performative inquiry course. They disappeared around a corner in the corridor to create and perform a scene about exile, leaving home.... acceptance. I have called them back into the classroom. "Black Out!" Pause. "Lights!"

Lit by fluorescent lights, a woman sinks to her knees on the floor. Her head, shoulders, upper body are enveloped under a multicolored scarf. She sings in a language I do not recognize. A second woman dances, she embraces pain, she becomes flight. Another arrives, gestures towards the singing woman, then speaks directly to us, in a language I cannot translate, but I understand every word. There is urgency in her voice. Something must be done. And a fourth woman raps, anger interweaving the urgency of the third woman, the troubled gestures of the dancer, and the unfolding melodies of the first woman, who sings throughout, like the calling of a river. Witnesses, we are held in the tension of the unfolding scene. 
And then, audience and performers, we arrive in silence. A lingering note holds the moment. The walls in the room have disappeared. This too is possible.

I leave the woods. I cross the campus and walk up well-worn steps into the Education Building, stomping snow off my boots as I cross the threshold into Karen's classroom. I arrive into community. Six of ustwo professors and four graduate students—-have come down the mountain, by car, bus, walking, to be here.

I am curious. How will Karen perform this class where we will be invited to interrupt the performance that is conventional academic writing? How might we understand performance in educational contexts? What is to be learned?

Karen welcomes us. She reads aloud from a children's story that she is writing. We lean into her words, as a new possible world is imagined into being. Here, in this moment, we encounter the performance that is education. A pedagogical invitation to shared vulnerability, imagination, curiosity. And as I listen, I awaken to the offering that is performance, as each moment, a child of duration, unfolds in our presence.

\section{Note}

1. Madeleine Grumet's invitation to "tread lightly, oh so lightly," was made during her presentation at the University of British Columbia in the mid-late 1990s.

\section{References}

Arendt, H. (1958). The human condition. University of Chicago Press.

Arendt, H. (1961). Between past and future: Six exercises of political thought. Viking.

Barba, E. (1995). The paper canoe: A guide to theatre anthropology. R. Fowler (Trans.). Routledge.

Brook, P. (1968). The empty space. Penguin.

Camus, A. (1991). Return to Tipasa in The myth of sisyphus and other essays (pp. 201-202). Vintage (reissue ed.).

Fels, L., \& Ortiz, B. (2019). Pedagogy of social circus: Launching the ball. In J.B. Spiegel \& B. Ortiz (Eds.), The art of collectivity: Social transformation, OEBuen Vivir and Ecuador's social circus in global perspective. McGill-Queen's University Press.

Fels, L. (1998). In the wind, clothes dance on a line. JCT: Journal of Curriculum Theorizing, 14(1), 27-36.

Fels, L. (1999). In the wind clothes dance on a line. Dissertation. University of British Columbia, Vancouver, British Columbia. Website.

Fels, L. (2009). Performative inquiry: Arresting the villains in Jack and the beanstalk. Journal for Learning Through the Arts. University of California. 
Fraser, P., Harrison, F., \& Fels, L. (2017). Artists speak. International Centre of Arts for Social Change. Simon Fraser University. Retrieved from https://icasc.ca/artists-speak

Freire, P. (1972). Pedagogy of the oppressed (Myra Bergman Ramos, Trans.). Penguin.

Greene, M. (1978). Landscapes of learning. Teachers College Press.

Leggo, C. (1994). Growing up perpendicular on the side of a hill. Killick.

Light, Sound, Movin' Around: What are Monsters Made of? (1996). Unpublished play created and performed by preservice teachers with Dr. Karen Meyer and Lynn Fels. University of British Columbia.

Meyer, K. (2006). Living inquiry - A gateless gate and a beach. In W. Ashton and D. Denton (Eds.), Spirituality, ethnography, and teaching: Stories from within. Peter Lang.

Meyer, K., \& Fels, L. (1998). Einstein, the universe and us: Science hits the stage: Performative inquiry within a co-evolving curriculum. JCT: Journal of Curriculum Theorizing, 14(1), 22-26. Retrieved from http://performativeinquiry.ca/pdfs/ScienceHitsTheStagePerfor.pdf

Meyer, K., \& Fels, L. (2014). Imagining education: An Arendtian response to an inmate's question. Canadian Journal of Education, 36(3), 298-316.

Milloy, J. (2007). Persuasions of the wild: Writing the moment, a phenomenology. Doctoral dissertation. Burnaby, BC: Simon Fraser University. British Columbia. Website.

Nachmanovitch, S. (1990). Free play: Improvisation in life and art. Jeremy P. Tarch/Putan.

Parker, M. (2017). A teacher in process: An illustrated exploration of art, education and what matters. Dissertation. Simon Fraser University. British Columbia. Website.

Sumara, D.J., \& Davis, B. (1997). Enlarging the space of the possible: Complexity, complicity, and action research practices. In T. Carson and D.J. Sumara (Eds.), Action research as a living practice, (pp. 299-312). Peter Lang.

Tarlington, C., \& Verriour, P., (1991). Role drama. Heinemann.

Thomasson, A. (2017). The gardener, the actor, and the educator: Six lessons towards creating and cultivating spaces of vulnerability between theatre for young audiences and education. Master thesis. Simon Fraser University, British Columbia. Website.

Thoreau, H.D. (1967). Walden pond. Washington Square.

Varela, F. (1987). Laying down a path in walking. In W.I. Thompson (Ed.), GAIA, a way of knowing: Political implications of the new biology (pp. 48-64). Lindisfarne. 


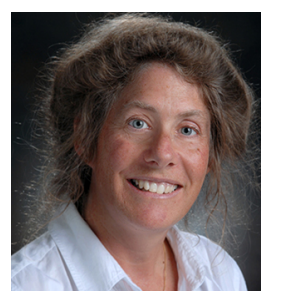

Lynn Fels is Professor at Simon Fraser University, British Columbia, Canada. Lynn has authored articles and chapters on performative inquiry, arts across the curriculum, and learning through lived experience. Recent research projects include mentorship, sense-making through play, and arts for social change. Lynn coauthored Exploring Curriculum: Performative Inquiry, Role Drama and Learning (Pacific Educational Press). She was Academic Editor of one of Canada's first open-access online academic journals, Educational Insights, which reimagines curriculum, research, and learning. Lynn is coeditor of Arresting Hope: Women Taking Action in Prison Inside Out and Releasing Hope: Women's Stories of Transition from Prison to Community (Inanna Press, 2015, 2019). She adores snow. 
Lynn Fels

22 | LEARNing Landscapes | Spring 2020, Vol. 13 